\title{
The high-molecular-weight glutenin subunit compositions of wheat varieties bred in Finland
}

\author{
TUULA SONTAG, HANNU SALOVAARA and PETER I PAYNE* \\ Department of Food Chemistry and Technology, University of Helsinki, \\ SF-00710 HELSINKI, Finland and
}

* Plant Breeding Institute, Maris Lane, Cambridge CB2 2LQ, U.K.

\begin{abstract}
The composition of high-molecular-weight (HMW) glutenin subunits in 35 Finnish bread wheat cultivars was determined by SDS-polyacrylamide gel electrophoresis. One third of the varieties have one of two HMW glutenin subunit compositions and there are only 17 different compositions in all. Three cultivars, Antti, Kiuru and Panu, are genetically mixed for some of these subunits. Cultivar Tammi (II) contains a novel HMW subunit of glutenin, not detected in any bread wheat previously analysed, and is presumed to be coded by genes on chromosome 1A at the Glu-Al locus. On the basis of previous work, which related individual subunits to bread-making quality, HMW glutenin subunit quality (Glu-1 quality) scores were calculated for the varieties. The results are related to the bread-making quality of Finnish wheats.
\end{abstract}

Index words: wheat, glutenin subunits, electrophoresis, quality

\section{Introduction}

The high-molecular-weight (HMW) subunits of glutenin are synthesised in the developing endosperm of wheat, which, at maturity, comprise some $10 \%$ of the storage protein of the grain. The subunits are coded by genes at three loci, Glu-Al Glu-Bl and Glu$D 1$, which occur on the long arms of chromosomes 1A, 1B and 1D respectively (PAYNE et al. 1982). Each locus exhibits extensive allelic variation (LAWRENCE and SHEPHERD, 1980) and this is partly responsible for the differ- ences in bread-making quality between cultivars (PAYNe et al. 1981 a). The HMW subunits of glutenin are best resolved by sodium dodecyl sulphate, polyacrylamide gel electrophoresis (SDS-PAGE) and this is the established method of identifying and cataloguing the various subunits (PAYNE and LAWRENCE, 1983). The procedure can also be used in conjunction with aluminium lactate-PAGE, which fractionates the gliadin proteins, to identify cultivars and to determine which of them contain biotypes for storage proteins (Zillman and Bushuk 1979). 
Table 1. Finnish wheat cultivars, the name of the breeder, the pedigree and the year of cultivar release.

\begin{tabular}{|c|c|c|c|c|}
\hline Cultivar & $\mathrm{W} / \mathrm{S}$ & Breeder & Pedigree & $\begin{array}{l}\text { Year of } \\
\text { cultivar } \\
\text { release }\end{array}$ \\
\hline 1. Antti & W & $\mathrm{Hja}$ & $\mathrm{F}_{1}(01216 \times$ Svea $) \times$ Ukrainka & 1955 \\
\hline 2. Aura & W & Jo & Ertus $\mathrm{x}$ Vakka & 1975 \\
\hline 3. Elo & W & $\mathrm{Hja}$ & Ta 07232 x Varma & 1963 \\
\hline 4. Ilves & W & $\mathrm{Hja}$ & Hja b $356 \times$ Vakka & 1975 \\
\hline 5. Jyvă & W & Jo & Line from Vakka & 1965 \\
\hline 6. Linna & W & $\mathrm{Hja}$ & Ta a $2701 \times$ Virtus & 1965 \\
\hline 7. Nisu & W & Jo & Line from Vakka & 1966 \\
\hline 8. Olympia & W & Jo & From landrace (Uusimaa) & 1941 \\
\hline 9. Panu & W & $\mathrm{Hja}$ & Svea $x$ landrace (Loimaa) & 1936 \\
\hline 10. Pitko & W & Jo & Ta 05901 x Vakka & 1985 \\
\hline 11. Pohjola & W & Jo & From landrace (Uusimaa) & 1933 \\
\hline 12. Sampo & W & Jo & Thule II $x$ landrace & 1933 \\
\hline 13. Sukkula & W & $\mathrm{Hja}$ & Line from landrace & 1922 \\
\hline 14. Sukkula II & W & $\mathrm{Hja}$ & From Sukkula I & 1928 \\
\hline 15. Vakka & W & Jo & Varma x Kehra & 1953 \\
\hline 16. Varma & W & $\mathrm{Hja}$ & Svea $x$ landrace (Orimattila) & 1933 \\
\hline 17. Villa & W & $\mathrm{Hja}$ & Line from landrace (Uusimaa) & 1921 \\
\hline 18. Apu & $\mathrm{S}$ & Jo & Garnet $x$ Pika & 1949 \\
\hline 19. Hopea & $\mathrm{S}$ & Jo & Marquis x Ruskea & 1936 \\
\hline 20. Kimmo & $\mathrm{S}$ & $\mathrm{Hja}$ & Line from Pisarev 2 & 1941 \\
\hline 21. Kiuru & $\mathrm{S}$ & Jo & Aurore $\mathrm{x}$ Sopu & 1951 \\
\hline 22. Luja & $\mathrm{S}$ & Jo & Svenno $\mathrm{x}$ (Hopea $\mathrm{x}$ Tammi) & 1981 \\
\hline 23. Pika & $\mathrm{S}$ & $\mathrm{Hja}$ & Ruskea $\mathrm{x}$ landrace (East Finland) & 1927 \\
\hline 24. Pika II & $\mathrm{S}$ & $\mathrm{Hja}$ & Canadian landrace $x$ Finnish landrace & 1934 \\
\hline 25. Ruskea & $\mathrm{S}$ & $\mathrm{Hja}$ & Line from landrace (Holland) & 1919 \\
\hline 26. Ruso & $\mathrm{S}$ & $\mathrm{Hja}$ & (Reward $x$ Pika) $x$ pollinator unknown & 1967 \\
\hline 27. Sopu & $\mathrm{S}$ & Jo & Marquis x Ruskea & 1935 \\
\hline 28. Taava & $\mathrm{S}$ & $\mathrm{Hja}$ & ${ }^{60} \mathrm{Co}$ mutant from Ruso & 1978 \\
\hline 29. Tähti & $\mathrm{S}$ & Jo & Kărni x (Aurore x Pika) & 1972 \\
\hline 30. Tammi (II) & $\mathrm{S}$ & $\mathrm{Hja}$ & McIntosh x Ta 01214 & 1938 \\
\hline 31. Tapio & $\mathrm{S}$ & $\mathrm{Hja}$ & Hja c 3929 x Kolibri & 1980 \\
\hline 32. Teră & $\mathrm{S}$ & $\mathrm{Hja}$ & Hopea x Ta 04609 & 1952 \\
\hline 33. Touko & $\mathrm{S}$ & Jo & Diamant $\mathrm{x}$ Hopea & 1950 \\
\hline 34. Ulla & $\mathrm{S}$ & $\mathrm{Hja}$ & Tammi x Ta a4431 & 1975 \\
\hline 35. Veka & $\mathrm{S}$ & $\mathrm{Hja}$ & Kärni x Tammi & 1970 \\
\hline
\end{tabular}

Abbreviations: Jo = Jokioinen, Agricultural Research Centre, Department of Plant Breeding

$\mathrm{Hja}=$ Hankkija Plant Breeding Institute

$\mathrm{W}=$ winter sown

$\mathrm{S}=$ spring sown

In this paper, we have used SDS-PAGE to determine the HMW glutenin subunit compositions of the 35 spring and winter wheat cultivars bred in Finland over the last 60 years. The results are related to the bread-making qualities of the varieties.

\section{Materials and methods}

Samples of 35 winter and spring wheat cultivars were obtained from the Finnish State
Seed Testing Station. The cultivars, the name of the breeder, the pedigree and the year of cultivar release are given in Table 1.

\section{SDS-PAGE}

Total protein was extracted from segments of three grains of each cultivar and fractionated by SDS-PAGE using $10 \%$ gels as described previously (PAYNE et al. 1980 and 1982). All the cultivars were extracted and 
analysed at least twice on separate gels. As described elsewhere (PAYNE et al. 1987) the presence or absence of subunit $2^{*}$ cannot be determined for cultivars which contain subunits $2+12$ but lack subunit 1 . Such cultivars were additionally analysed using $5 \%$ gels (PAYNE et al. 1981 b) which clearly resolves subunit 2 from $2 *$. The numbering system for the HMW glutenin subunits is that described by PAYNE and LAWRence (1983).

\section{Results}

A typical fractionation of cultivar grain proteins by SDS-PAGE is shown in Fig. 1. The area of the gel containing the HMW subunits of glutenin is marked by brackets and they have been given numbers according to standardised nomenclature (PAYNE and LAwRENCE, 1983). All the subunits but one in the set of 35 cultivars have been described previously. The exceptional subunit, found in cultivar Tammi (II), was assumed to be coded by genes on chromosome 1A at the Glu-Al locus because the cultivar contained its full allocation of 1B- and 1D-encoded subunits, but none by chromosome $1 \mathrm{~A}$. In addition, the subunit occurred as a thin band of slow mobility (Fig. 1, slot 4) typical of the commonly occurring 1A-encoded subunits 1 and $2 *$ (Fig. 1 , slots 3 and 5 respectively). It is proposed to number the subunit 25 and to call the allele Glu-Ald. This information will be included in the next update of the HMW glutenin subunit catalogue, with Tammi (II) as the standard.

The HMW glutenin subunit compositions of the 35 cultivars are listed in Table 2. On the basis of analysing six grains per cultivar only, four cultivars (Antti, Kiuru, Panu and Tammi (II) were shown to consist of at least two biotypes with different HMW glutenin subunits. Antti and Kiuru each contained two alleles at $G l u-A 1$, the predominant one coding for subunit 1 and the other, the null allele, which does not produce a subunit. The sample of Panu grain analysed was highly

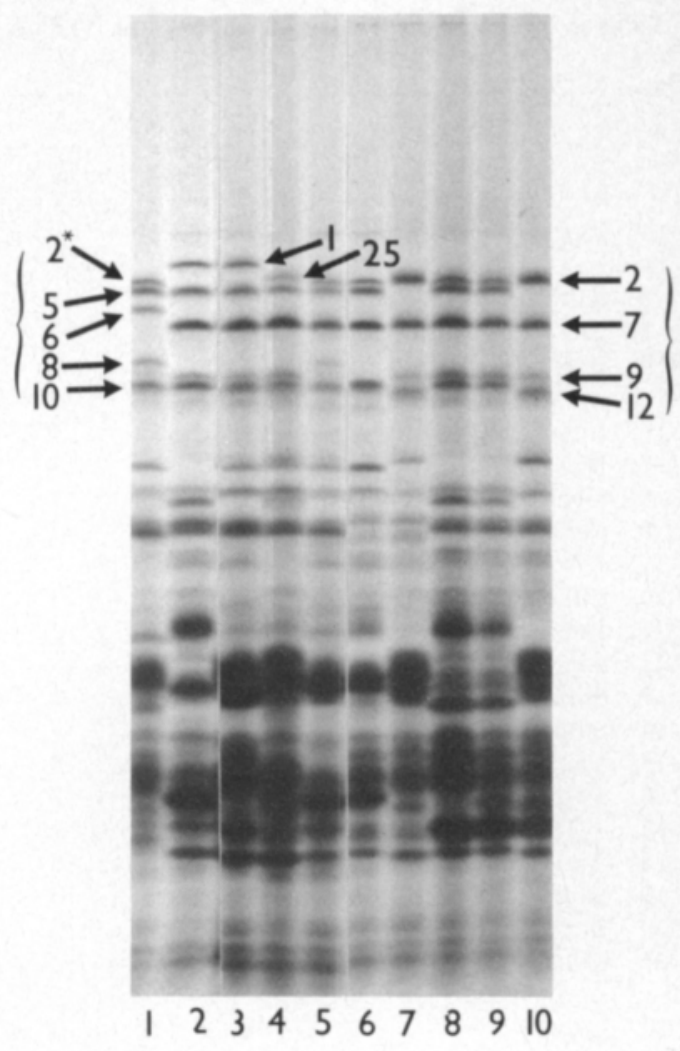

Fig. 1. SDS-PAGE of Finnish cultivars: slots 1, Veka; 2, Ruso; 3, Kimmo; 4, Tammi (II); 5, Hopea; 6, Ilves; 7, Aura; 8, Nisu; 9, Jyvă; 10, Linna. The region of the gel containing the HMW subunits of glutenin is enclosed by brackets. The subunits have been numbered according to the nomenclature of PAYNE and LAWRENCE (1983).

mixed, for it contained two alleles at all three Glu-1 loci.

Most of the cultivars analysed have also been given a HMW glutenin subunit quality (Glu-1 quality) score in Table 2. This was calculated by summing the scores assigned previously to individual subunits as shown in Table 3. Unfortunately cultivars Panu, Sampo and Tammi (II) could not be given a Glu-1 quality score because they each contained a HMW glutenin subunit which has not yet been associated with bread-making quality; subunit 20 for the first two cultivars and subunit 25 for Tammi (II). The Glu-1 quality score of a cultivar can range from a minimum of 3 to a maximum of 10 . For wheat varieties bred 
Table 2. HMW glutenin subunit composition on Finnish varieties.

\begin{tabular}{|c|c|c|c|c|c|}
\hline \multirow[t]{2}{*}{ Variety } & \multirow[t]{2}{*}{$\mathrm{W} / \mathrm{S}$} & \multicolumn{4}{|c|}{ HMW subunits } \\
\hline & & $1 \mathrm{~A}$ & 1B & 1D & Score ${ }^{++}$ \\
\hline 1. Antti & W & $\begin{array}{l}1 \\
(\mathrm{~N})\end{array}$ & $7+9$ & $5+10$ & $\begin{array}{l}9 \\
-\end{array}$ \\
\hline 2. Aura+ & W & $2^{*}$ & $7+9$ & $2+12$ & 7 \\
\hline 3. Elo & W & 1 & $7+9$ & $2+12$ & 7 \\
\hline 4. Ilves ${ }^{+}$ & W & $2^{*}$ & 7 & $5+10$ & 8 \\
\hline 5. Jyvã & W & $2 *$ & $7+9$ & $5+10$ & 9 \\
\hline 6. Linna ${ }^{+}$ & W & $2^{*}$ & $7+9$ & $2+12$ & 7 \\
\hline 7. $\mathrm{Nisu}^{+}$ & W & $2^{*}$ & $7+9$ & $5+10$ & 9 \\
\hline 8. Olympia & W & 1 & $7+9$ & $2+12$ & 7 \\
\hline 9. Panu & W & $\begin{array}{l}2^{*} \\
(\mathrm{~N})\end{array}$ & $\begin{array}{l}20 \\
\text { (7) }\end{array}$ & $\begin{array}{c}2+12 \\
(5+10)\end{array}$ & - \\
\hline 10. Pitko ${ }^{+}$ & W & 1 & 7 & $5+10$ & 8 \\
\hline 11. Pohjola & W & $2^{*}$ & $7+9$ & $2 * 12$ & 7 \\
\hline 12. Sampo & W & 1 & 20 & $2+12$ & - \\
\hline 13. Sukkula & W & $2^{*}$ & $7+9$ & $2+12$ & 7 \\
\hline 14. Sukkula II & W & $2^{*}$ & $7+9$ & $2+12$ & 7 \\
\hline 15. Vakka ${ }^{+}$ & W & $2^{*}$ & 7 & $5+10$ & 8 \\
\hline 16. Varma & W & 1 & $7+9$ & $2+12$ & 7 \\
\hline 17. Villa & W & $2^{*}$ & $7+9$ & $2+12$ & 7 \\
\hline 18. Apu & $\mathrm{S}$ & $\mathrm{N}$ & $7+8$ & $2+12$ & 6 \\
\hline 19. Hopea & $\mathrm{S}$ & $2^{*}$ & $7+8$ & $5+10$ & 10 \\
\hline 20. Kimmo & $\mathrm{S}$ & 1 & $7+9$ & $5+10$ & 9 \\
\hline 21. Kiuru & $\mathrm{S}$ & $\begin{array}{l}1 \\
(\mathrm{~N})\end{array}$ & $7+8$ & $5+10$ & 10 \\
\hline 22. Luja ${ }^{+}$ & $\mathrm{S}$ & $2^{*}$ & $7+8$ & $5+10$ & 10 \\
\hline 23. Pika & $\mathrm{S}$ & $2^{*}$ & $7+8$ & $2+12$ & 8 \\
\hline 24. Pika II & $\mathrm{S}$ & $\mathrm{N}$ & $7+9$ & $2+12$ & 5 \\
\hline 25. Ruskea & $\mathrm{S}$ & $2^{*}$ & $7+8$ & $2+12$ & 8 \\
\hline 26. Ruso ${ }^{+}$ & $\mathrm{S}$ & 1 & $7+9$ & $5+10$ & 9 \\
\hline 27. Sopu & $\mathrm{S}$ & $2^{*}$ & $7+8$ & $5+10$ & 10 \\
\hline 28. Taava ${ }^{+}$ & $\mathrm{S}$ & 1 & $7+9$ & $5+10$ & 9 \\
\hline 29. Tähti ${ }^{+}$ & $\mathrm{S}$ & 1 & $7+9$ & $5+10$ & 9 \\
\hline 30. Tammi (II) & $\mathrm{S}$ & $\begin{array}{l}25 \\
(\mathrm{~N})\end{array}$ & $7+9$ & $5+10$ & - \\
\hline 31. Tapio & $\mathrm{S}$ & $\mathrm{N}$ & $7+9$ & $5+10$ & 7 \\
\hline 32. Terä & $\mathrm{S}$ & 1 & $7+9$ & $5+10$ & 9 \\
\hline 33. Touko & $\mathrm{S}$ & $\mathrm{N}$ & $7+8$ & $5+10$ & 8 \\
\hline 34. Ulla & $\mathrm{S}$ & $2^{*}$ & $7+9$ & $5+10$ & 9 \\
\hline 35. Veka & $\mathrm{S}$ & $2 *$ & $6+8$ & $5+10$ & 8 \\
\hline
\end{tabular}

+ Currently grown commercially

++ Glu-1 quality score, as discussed in the text

in Finland, the range is from 5 to 10 with an average of 8.0 , which is very high.

The 35 cultivars contain 17 different permutations of HMW glutenin subunits (Table 4). However, one third of the cultivars contain one of two HMW subunit compositions: $1,7+9$ and $5+10$, and $2 *, 7+9$ and $2+12$. Only nine of the cultivars have compositions that are unique in this collection.
Table 3. Bread-quality scores assigned to HMW subunits of glutenin.

\begin{tabular}{cccc}
\hline \multirow{2}{*}{ Score } & \multicolumn{3}{c}{ Chromosome } \\
\cline { 2 - 4 } & $1 \mathrm{~A}$ & $1 \mathrm{~B}$ & $1 \mathrm{D}$ \\
\hline 4 & - & - & $5+10$ \\
3 & 1 & $7+8$ & - \\
& $2^{*}$ & $17+18$ & - \\
2 & - & $7+9$ & $3+12$ \\
& - & - & $3+12$ \\
1 & null & 7 & $4+12$ \\
& & $6+8$ & \\
\hline
\end{tabular}

Further details on the assignments are described by PAYNe et al. (1987).

Table 4. Frequencies of various HMW glutenin subunit compositions amongst varieties.

\begin{tabular}{|c|c|c|c|c|c|}
\hline & \multicolumn{3}{|c|}{ Subunit composition } & \multirow[t]{2}{*}{ No. } & \multirow[t]{2}{*}{$\%$} \\
\hline & $1 \mathrm{~A}$ & 1B & 1D & & \\
\hline 1. & 1 & 7 & $5+10$ & 1 & 3 \\
\hline 2. & 1 & $7+8$ & $5+10$ & 1 & 3 \\
\hline 3. & 1 & $7+9$ & $2+12$ & 3 & 8 \\
\hline 4. & 1 & $7+9$ & $5+10$ & 6 & 17 \\
\hline 5. & 1 & 20 & $2+12$ & 1 & 3 \\
\hline 6. & $2^{*}$ & $6+8$ & $5+10$ & 1 & 3 \\
\hline 7. & $2^{*}$ & 7 & $5+10$ & 2 & 6 \\
\hline 8. & $2^{*}$ & $7+8$ & $2+12$ & 2 & 6 \\
\hline 9. & $2^{*}$ & $7+8$ & $5+10$ & 3 & 8 \\
\hline 10. & $2^{*}$ & $7+9$ & $2+12$ & 6 & 17 \\
\hline 11. & $2^{*}$ & $7+9$ & $5+10$ & 3 & 8 \\
\hline 12. & $2^{*}$ & 20 & $2+12$ & 1 & 3 \\
\hline 13. & $\mathrm{~N}$ & $7+8$ & $2+12$ & 1 & 3 \\
\hline 14. & $\mathrm{~N}$ & $7+8$ & $5+10$ & 1 & 3 \\
\hline 15. & $\mathrm{~N}$ & $7+9$ & $2+12$ & 1 & 3 \\
\hline 16. & $\mathrm{~N}$ & $7+9$ & $5+10$ & 2 & 6 \\
\hline 17. & 25 & $7+9$ & $5+10$ & 1 & 3 \\
\hline
\end{tabular}

The above data includes the major biotypes only of Antti, Kiuru and Panu.

\section{Discussion}

Previous studies have shown that there is a positive correlation between the Glu-1 quality score of cultivars from several Western European countries and their bread-making qualities (PAYNE, 1986; PAYNE et al. 1987). By contrast there is a negative correlation between the score and the biscuit-making quality of 
UK-grown wheats (PAYnE, et al. 1987). The Glu-1 quality score is probably therefore an indirect measure of dough strength. Finnish cultivars have the very high, average score value of 8.0. This is much higher than the mean scores of cultivars grown in the UK, West Germany (5.2 and 5.8 respectively; PAYNE and HoLt, unpublished data) and France (5.8; calculated from BRANLARD and Le Blanc, 1985), but the same as the average score of cultivars grown in Australia (8.0; calculated from LAWRENCE, 1986). The cause of the high mean score value fro Finnish cultivars is probably the long tradition in this country of breeding and growing wheat primarily for conversion into bread (Kıvı, 1969), whereas in the UK for example, wheats are specifically bred and grown for at least three different end uses: bread, biscuits and animal feed.

The mean Glu-1 quality score of winter wheats currently grown in agriculture in Finland is 7.8, whereas for spring wheats the average score is even higher, at 8.8 . There is therefore some prospect of improving the score of Finnish winter wheats in future varieties whereas one of the objectives for spring wheats should be to maintain the current, high score.

The range and distribution of HMW glutenin subunits found in Finnish-bred varieties is very limited compared to varieties grown elsewhere in Europe. Thus the chromosome $1 \mathrm{~A}$-encoded null allele is rare. Of the chromosome 1B-encoded subunits, subunit 7 is found only in Vakka, Ilves and Pitko and $6+8$ only in Veka. Subunits $4+12$ and $3+12$, coded by genes on chromosome 1D, are not found in any variety. The scarcity or absence of these subunits is advantageous because all of them have been associated with either mediocre or poor bread-making quality. However, if breeders in future use parental lines with greater genetic diversity than those currently used, these poor-quality subunits may be introduced into breeding programmes. SDSPAGE of embryoless half-grains could then be used to advantage to screen against these subunits in subsequent generations.

Subunits $17+18$ are not present in any of the cultivars listed in Table 2 . They are coded by genes on chromosome 1B and have been associated with good bread-making quality (PAYNe et al. 1984). The subunits are common in cultivars of Australia and Central and Southern America (LAwrence, 1986; PAYNE, unpublished) and they have recently been introduced into the UK, France and Spain, in germplasm containing reduced-height $(R h t)$ genes. It would be advantageous to transfer these storage-protein genes into Finnish wheats also.

The limited number of combinations of HMW glutenin subunits amongst Finnish wheats causes SDS-PAGE to be of little value in varietal identification. By contrast, aluminium lactate-PAGE of the gliadin proteins has been successfully used to distinguish all the varieties that are currently grown in Finland (Sontag and SalovaAra, 1985), except for Ruso and Taava. However, SDS-PAGE can easily detect the presence of protein biotypes in wheat cultivars. In the very preliminary study described here, based only on the analysis of six grains per cultivar, three varieties were shown to be genetically mixed (Table 2). Currently the presence of storage-protein biotypes in Finnish cultivars in agriculture is being examined in much more detail.

Acknowledgements. We are grateful to chief inspector Osmo Ulvinen in the Finnish Seed Testing Station for the wheat cultivar samples.

\section{References}

Branlard, G. \& Le Blanc, A. 1985. Glutenins of bread and durum wheat cultivars in France. Agronomie 5: $467-477$.

Kıvı, E.I. 1969. Sadon käyttöarvo kevătvehnănjalostuksen tavoitteena. Ann. Agric. Fenn. 8: 193-204. Lawrence, G.J. \& Shepherd, K.W. 1980. Variation in 
glutenin protein subunits of wheat. Aust. J. Biol. Sci 33: $221-233$.

Lawrence, G.J. 1986. The high-molecular weight glutenin subunit composition of Australian wheat cultivars. Aust. J. Agric. Res. 37: 125-133.

Payne, P.I., Law, C.N. \& Mudd, E.E. 1980. Control by homoeologous group 1 chromosomes of the high-molecular-weight subunits of glutenin, a major protein of wheat endosperm. Theor. Appl. Genet. 58: 113-120.

Payne, P.I., Corfield, K.G., Holt, L.M. \& Blackman, J.A. 1981 a. Correlations between the inheritance of certain high-molecular-weight subunits of glutenin and bread-making quality in progenies of six crosses of bread wheat. J. Sci. Fd. Agric. 32: 51-60.

Payne, P.I., Holt, L.M. \& Law, C.N. 1981 b. Structural and genetical studies on the high-molecular weight subunits of wheat glutenin. Part 1; Allelic variation in subunits amongst varieties of wheat (Triticum aestivum). Theor. Appl. Genet. 60: 229-236.

Payne, P.I., Holt, L.M., Worland, A.J. \& Law, C.N. 1982. Structural and genetic studies on the high-molecular-weight subunits of wheat glutenin. Part 3 . Telocentric mapping of the subunit genes on the long arms of the homoeologous group 1 chromosomes. Theor. Appl. Genet. 63: 129-138.

Payne, P.I. \& Lawrence, G.J. 1983. Catalogue of alleles for the complex gene loci, Glu-A1, Glu-Bl, Glu-DI which code for high-molecular weight subunits of glutenin in hexaploid wheat. Cer. Res. Commun. 11: 29-35.

Payne, P.I., Holt, L.M., Jackson, E.A. \& Law, C.N. 1984. Wheat storage proteins: their genetics and their potential for manipulation by plant breeding. Phil. Trans. R. Soc. Lond. B304: 359-371.

PAYNE, P.I. 1986. Varietal improvement in the breadmaking quality of wheat: contributions from biochemistry and genetics, and future prospects from molecular biology. 1986 BCPC Mono. No. 34. Biotechnology and crcp improvement and crop protection. pp 69-81.

Payne, P.I., Nightingale, M.A., Krattiger, A.F.V. \& Holt, L.M. 1987. The relationship between HMW glutenin subunit composition and the bread-making quality of British-grown wheat varieties. J. Sci. Fd. Agric. In the press.

Sontag, T. \& Salovaara, H. 1985. PAG electrophoregrams of wheat cultivars grown in Finland. J. Agric. Sci. Finl. 57: 271-277.

ZILLMAN, R.R. \& BuSHUK, W. 1979. Wheat cultivar identification by gliadin electrophoregrams. III. Catalogue of electrophoregram formulas of Canadian wheat cultivars. Can. J. Pl. Sci. 59: 287-298.

Ms received September 22, 1986

\section{SELOSTUS}

\section{Suomessa jalostettujen vehnälajikkeiden suurimolekyylisten gluteniinialayksiköiden koostumus}

\section{Tuula Sontag, Hannu Salovaara ja Peter I Payne*}

\author{
Helsingin yliopiston elintarvikekemian ja \\ -teknologian laitos, \\ 00710 Helsinki ja \\ * Plant Breeding Institute, Maris Lane, \\ Cambridge CB2 $2 L Q$, U.K.
}

Suomessa jalostettujen vehnălajikkeiden (35) suurimolekyyliset gluteniinialayksikőt määritettiin SDS-polyakryyliamidigeelielektroforeesilla. Suomalaisista vehnälajikkeista löytyi vain 17 erilaista alayksiköiden yhdistelmäă ja kolmasosa lajikkeista jakaantui kahden alayksikköyhdistelmăn vălille. Tutkituista lajikkeista neljă, Antti, Kiuru, Panu ja Tammi (II), olivat jonkin suurimolekyylisen gluteniinialayksikkőnsă suhteen geneettisesti sekoittuneita. Tammi (II)-lajikkeesta löytyi uusi suurimolekyy- linen gluteniinialayksikkő (25), jota ei leipăvehnillă ole aikaisemmissa tutkimuksissa löytynyt. Kromosomin 1A lokuksessa Glu-A1 olevien geenien oletetaan ohjaavan tämän gluteniinialayksikön (25) tuotantoa. Tutkittujen lajikkeiden suurimolekyylisten gluteniinialayksikőiden leivontalaatupisteet laskettiin aikaisemmissa tutkimuksissa osoitettujen gluteniinialayksikőiden ja leivontalaadun yhteyksien perusteella. 